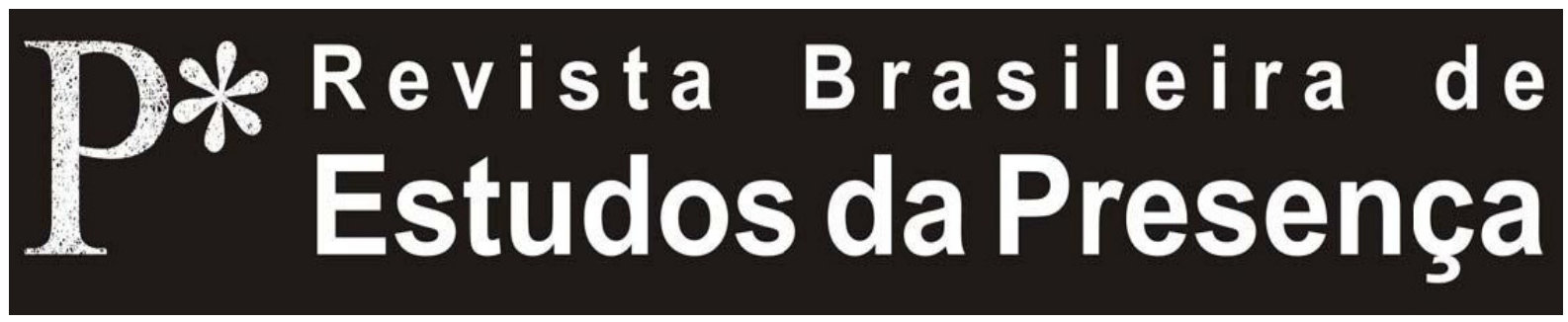

DOI - http://dx.doi.org/10.1590/2237-266030380

ISSN 2237-2660

\title{
A Antropofagia da Usina do Trabalho do Ator
}

Clóvis Dias Massa

Universidade Federal do Rio Grande do Sul - UFRGS, Porto Alegre, RS, Brasil

RESUMO - A Antropofagia da Usina do Trabalho do Ator - Este texto conjuga a aproximação entre a teatralidade das manifestações orientais com o trabalho prático do Núcleo de Investigação - Usina do Trabalho do Ator (UTA). Trata-se aqui de estabelecer vínculos entre a teoria da recepção proposta por Richard Schechner a partir do teatro rásico e a teatralidade presente em vários espetáculos da UTA. Examina-se de que forma o grupo empregou os procedimentos antropofágicos em quatro de suas montagens e qual o papel do espectador em suas composições cênicas.

Palavras-chave: Teatro em Porto Alegre. Antropofagia Teatral. Usina do Trabalho do Ator.

ABSTRACT - The Cannibalism of Usina do Trabalho do Ator - This text conjugates the rapprochement between the theatricality of Eastern manifestations and the practice of Usina do Trabalho do Ator (UTA) Research Group. We establish links between the theory of reception proposed by Richard Schechner based on rasic theatre and the theatricality of several UTA spectacles. We also examine the way in which the group used cannibalistic procedures in four stagings as well as the role of the audience in their scenic compositions.

Keywords: Theatre in Porto Alegre. Theatrical Cannibalism. Usina do Trabalho do Ator.

RÉSUMÉ - L'Anthropophagie de l'Usina do Trabalho do Ator - Ce texte établit un rapprochement entre la théâtralité des manifestations orientales et le travail pratique du Núcleo de Investigaçao teatral Usina do Trabalho do Ator (UTA). Il s'agit ici de tisser des liens entre la théorie de la réception proposée par Richard Schechner à partir du théâtre rasa et la théâtralité présente dans de nombreux spectacles de l'UTA. L'interrogation porte enfin sur la manière dont la compagnie a utilisé les procédures anthropophagiques dans quatre de ses spectacles et sur le rôle accordé au spectateur dans ces compositions scéniques.

Mots-clés: Théâtre à Porto Alegre. Anthropophagie Théâtrale. Usina do Trabalho do Ator. 
Antes dos portugueses descobrirem o Brasil,

o Brasil tinha descoberto a felicidade.

[...] A alegria é a prova dos nove

Oswald de Andrade

$\mathrm{O}$ teatro enquanto ponto de vista sobre um acontecimento articula o conceito de teatralidade a um significado que, num primeiro momento, salienta sua propriedade de construção artística por meio do olhar. A esse respeito, como tantos outros autores que recordam a etimologia do termo que deu origem ao teatro, como um lugar de/para ver, Richard Schechner, em seu livro Performance, Teoría y Prácticas Interculturais, parte da comparação entre a poética aristotélica e a Natyasastra de Bharata-muni para esboçar uma teoria da recepção sobre as práticas teatrais contemporâneas.

$\mathrm{Na}$ visão de Schechner, a Arte Poética de Aristóteles, escrita cem anos após a época da grande tragédia grega, é um texto lacônico que não descreve as performances reais, trata apenas do drama, não do teatro, trazendo em seu texto o caráter histórico sobre o que a tragédia foi, e, a partir do modelo de Édipo Rei, de Sófocles, acaba por normatizar o gênero no futuro. Já o Natyasastra, o manual hindu, escrito não por um filósofo que influenciou e determinou o pensamento ocidental em vários campos, mas provavelmente compilado por Bharata-muni a partir de um saber oral sobre as origens mítico-religiosas das práticas de natya, que abrangem dança, teatro e música numa manifestação única. Os gêneros tradicionais, como o Kathakali, o Bharatanatyam e o Odissi alcançam essa integração de maneira a privilegiar a dança, o gesto e a música e, segundo ele, dar menos importância ao enredo.

É com base no que Natyasastra descreve sobre o rasa que Schechner chega à sua teoria da recepção ou rasaestética, como ele denomina. Rasa é um sabor, um gosto, uma sensação que temos quando tocamos a comida, a levamos na boca, a mastigamos, a misturamos e a saboreamos. Enquanto que a mão leva a comida à boca, o nariz, enfim, todo o rosto está envolvido. Por isso entram em questão os vários sentidos, especialmente o gosto, o olfato e o tato, mas também a visão e a audição. Uma estética fundada no rasa é, para ele, funda- 
mentalmente diferente de uma estética fundada no theatron (que gira em torno de estratégias para olhar), pois objetiva o prazer, e não a competição grega, e se vale dos meios parecidos com a combinação e a transformação de elementos diferentes em uma nova mistura que oferece sabores e gostos peculiares.

O prazer do participante (espectador) é semelhante ao prazer das pessoas que provam uma comida preparada com uma mistura de diferentes condimentos e molhos. O teatro rásico, como ele chama, valoriza a experiência desta combinação de elementos, provocando o gozo dos participantes por meio da variedade das emoções expressadas pelos atores em palavras, gestos e sentimentos. Trata-se de um cardápio de muitas delícias, das quais nem todas se pode saborear de uma vez. Tem-se uma ideia do rásico comparando o teatro hindu com o estilo Ajanta na pintura e na escultura. As grutas de Ajanta em Deccan Aurangabad, a um dia de viagem de Mumbai (Bombai), se aproximam desse tipo de experiência a que Schechner se refere, visto que esse tipo de estrutura induzia no passado a participação total do espectador com uma hábil combinação de experiências sensoriais. O efeito de envolvimento das grutas se transmitia através da encantação védica.

Com efeito, a experiência compartilhada da combinação entre teatro, dança, música, comida e devoção religiosa não se reduz a nenhuma categoria religiosa, estética, pessoal ou gustativa. Ao contrário, dissolve qualquer diferenciação, sendo uma experiência difícil de medir de dentro ou de fora. $\mathrm{O}$ caráter peculiarmente interior da teatralidade como experiência compartilhada é o que distingue a rasaestética da estética grega, pois nela se experimenta nas tripas.

A clara preferência de Schechner pelo manual sânscrito, em oposição à arte poética de Aristóteles, que não se detém sobre o trabalho do ator, é justificada pela acepção da representação presente na poética aristotélica, por meio do termo mímesis com o sentido de dar a ver e apresentar diante do olhar, ao mostrar, fabricar, exibir para os olhos. Entretanto, compreendemos que a definição presente no manual sânscrito do Natyasastra também é encontrada no texto de Platão, a quem Aristóteles parece responder em sua Arte Poética, já que o estagirita não concorda com sua concepção de mímesis. 
Para Platão, em especial nos livros III e X de A Repúbli$c a$, a mímesis separa e opõe a imitação e o que ela mostra (ou pretende mostrar), ou seja, a imagem e a ideia. Deste modo, a mímesis (e, portanto, o teatro que se faz) não seria apenas mera imitadora. Platão concebe a mímesis como a ação de representar a ação, visto que estabelece assim uma diferença entre a ação representada e a ação de representar.

Ao encontro dessa noção, Dénis Guénoun, em seu $O$ Teatro é Necessário?, afirma que o ator se instala justamente nesse afastamento, ao assumir a ação de representar, na medida em que ela se distingue da ação representada. Esse aspecto pode ser inclusive ilustrado com a teoria da recepção que Schechner propõe com o exemplo do Bharatanatyam, Odissi ou Kathakali. Os participantes, como ele chama os espectadores, olham a performance a uma certa distância, isto é, de maneira semelhante como no Ocidente, através dos olhos e dos ouvidos. Porém, pela tradição hindu, como se costuma dizer, onde vai a mão, o olho segue: o costume de levar a comida do prato à boca diretamente com a mão direita, sem talher ou instrumento intermediário, usando-se às vezes um pedaço de pão para pegar a comida do prato ou o arroz para absorver o curry, faz com que, em todos os casos, se saboreie os próprios dedos.

Assim, também na dança hindu, a atriz-dançarina olha suas mãos com frequência, não com narcisismo, mas para reconhecer que, usando os gestos e expressões apropriados, será ela mesma afetada por sua performance. Cria-se, com isso, um espaço liminar entre ela e os participantes, segundo Schechner, pois a atriz, ao preparar e compartilhar a performance, converte-se ela mesma em participante, olhando a si mesma e sentindo o prazer de sua performance. Por isso, o interesse dos participantes não é pelo que vai acontecer na história, e sim experienciar o modo como a atriz atua. A atriz da dança clássica indiana prepara um banquete e desfruta do que preparou junto com os espectadores.

Partimos dessa noção de teatralidade, para além da relação entre o olhar e a visão do objeto olhado, na constituição dinâmica de um mundo real produzido por uma construção 
espetacular e uma ficção representada, para examinar de que maneira assoma a teatralidade nos espetáculos da Usina do Trabalho do Ator. A escolha do núcleo é coerente pelo modo como são perceptíveis na formação de seus integrantes as mudanças importantes que se realizaram na prática teatral na últimas décadas, "[...] proveniente, entre outros, das teorias de Grotowski e Eugenio Barba. Nelas se considera a existência de formas de atuação não limitadas a uma cultura, mas transculturais" (Villegas, 2010, p. 91). Como as pesquisas do grupo em relação com o espaço incluem experiências em diferentes salas, apresentando espetáculos tanto em palco à italiana como em espaços alternativos, e tendo, muitas vezes, a rua como espaço cênico, aproveitamos para destacar quatro espetáculos que fazem parte da extensa trajetória do grupo, em que se enfatizam os elementos teatralizados, tais como a presença de pernas de pau, o emprego de instrumentos musicais e o uso de máscaras.

Klaxon, apresentado uma única vez após dois anos de trabalho intensivo, no Teatro Carlos Carvalho, em setembro de 1994, durante o $\mathrm{I}^{\circ}$ Festival Internacional de Artes Cênicas Porto Alegre em Cena, foi elaborado a partir da improvisação dos atores, com base em poemas, músicas e pinturas. Tinha como estrutura e temática o Carnaval, com personagens em transe desfilando suas fantasias pela passarela montada para ser o espaço de atuação. Entre os personagens, destacavam-se o Hierofante, que escondia dentro de si uma Bailarina Boba; o Macunaíma, o herói sem caráter; uma Lavadeira que sonhava em ser Rainha do Carnaval; o Estrangeiro e a Criola Doida, que vinham ao desfile na busca da terra prometida, encontravamse, aliavam-se e se rechaçavam. Nessa primeira experiência antropofágica do grupo, a identidade nacional era vista a partir dos arquétipos do homem brasileiro em seu caráter mais universal sobre o tema. Ainda que a obra de Mário de Andrade e a montagem de Antunes Filho sobre Macunaima lhe tenham servido de fonte para a criação, o tipo de processo concentrouse na aproximação do tema sem pretender, propriamente, um novo tratamento para a manifestação carnavalesca.

Foi, no entanto, com a montagem de $O$ Ronco do Bugio, primeiro espetáculo do projeto Trilogia Mascarada, no qual a 
máscara é trabalhada sem suporte, com a maquiagem transformando o rosto do ator, que a apropriação do universo gaúcho passou a encontrar resultados antropofágicos mais relevantes. A história de Antônio Chimango, escrita por Ramiro Barcelos sob o pseudônimo de Amaro Juvenal, serviu de fonte para a aplicação de técnicas de treinamento numa montagem de rua que tinha como temática a associação da figura do bugio, macaco ameaçado de extinção presente na região Sul do Brasil, com o bufão, visto que ambos são grotescos, marginalizados e andam em bandos. Assim, cansados de morrerem pelas mãos dos fazendeiros, os bugios personificados no espetáculo vinham à cidade cantar velhas histórias.

Dispostos, nesse trabalho, a investigar o trabalho do bufão sem o peso da atmosfera medieval, o resultado é a criação de um tipo de bufão contemporâneo que permite a rápida identificação com o público.

\footnotetext{
Sábado, 11h. Sol a pino. Bugios estilizados surgem entre as árvores do Parque Farroupilha, ao lado da piscina central. São apenas 16 atores, mas o efeito causado pelo sol, pelas roupas coloridas e pela maquiagem parece multiplicar a quantidade de bufões em cena [...]. Bastante à vontade e seguros, os atores conduzem o espetáculo com sua cantoria e espontaneidade para contar a história do peão que chega a coronel e absorve os vícios do poder. Quem está passando, não resiste a uma paradinha, e a maioria acaba mesmo ficando, aguentando o calor e a falta de acomodação formal (Martins, 1996, p. 06).
}

Os recursos de cada local de apresentação eram aproveitados pelos atores, instituindo uma forma de se apropriar do espaço que remete ao fazer teatral na rua, e não exatamente de rua. A ação acontecia em quatro diferentes espaços, com os espectadores sendo conduzidos pelos bugios aos locais da ação. 


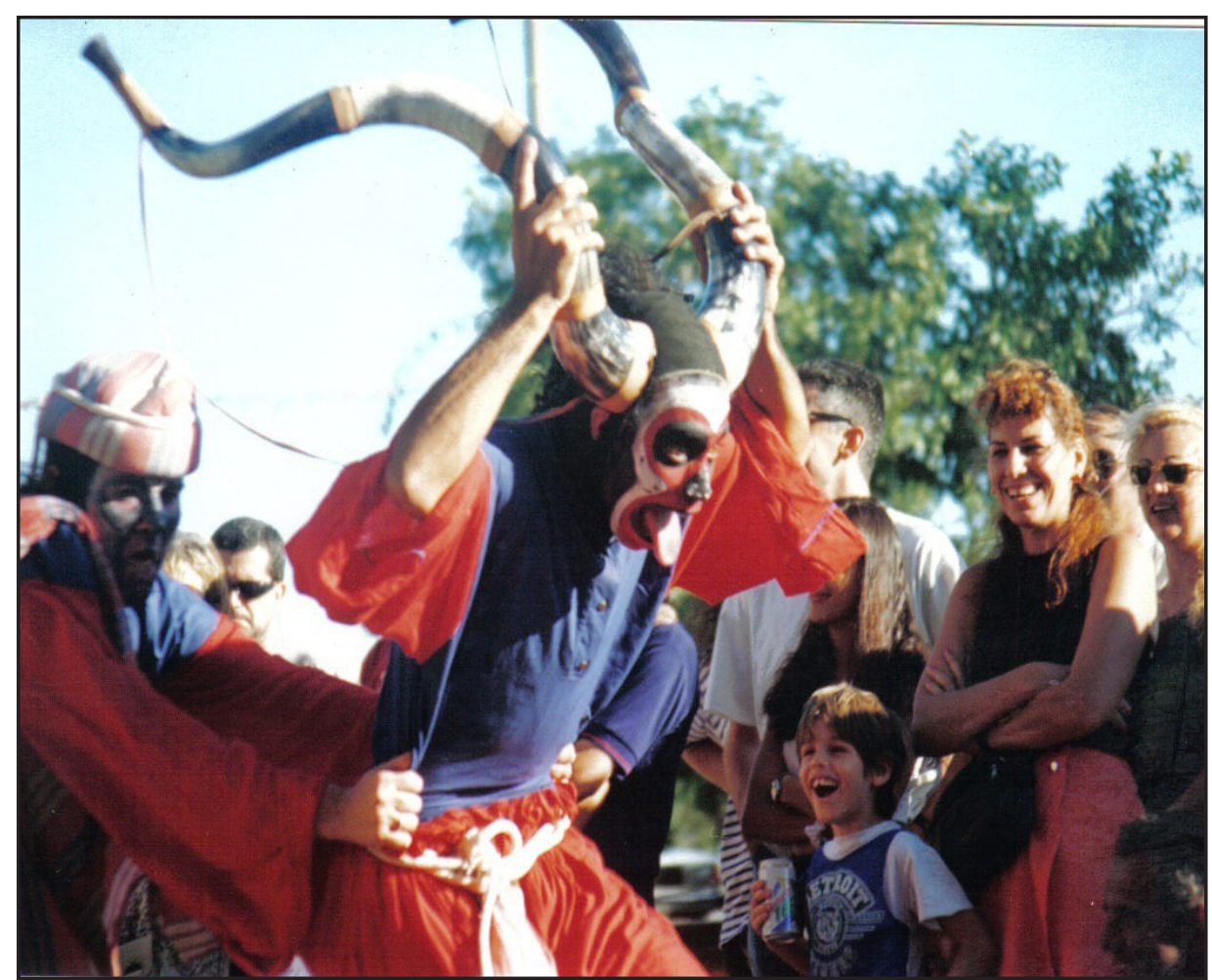

Figura 1 - Arlete Cunha e Marcelo di Paula em O Ronco do Bugio, de 1998. Fotografia de Marinéli Meliga.

Já em Mundéu, o Segredo da Noite, de 1998, segundo espetáculo do projeto Trilogia Mascarada, a máscara também foi empregada sem suporte, da mesma forma como em $O$ Ronco do Bugio. Tomando como base a obra Lendas do Sul, de Simões Lopes Neto, numa montagem que podia ser apresentada tanto na rua como nos palcos, sua principal linguagem era a dança. O ritual era realizado pelos atores que, ao som dos tambores, invocavam espíritos lendários que se personificavam para contar a história de amor de um homem e de uma mulher surpreendidos por Anhangá-Pitã, demônio que faz cair a noite e despertar a cobra de fogo, conhecida como Boitatá. A grande cobra devora os olhos da mulher e a dor do seu amado comove Salamanca: uma Princesa Moura transformada em Lagartixa. Por fim, a Salamanca revela ao homem as três provas mágicas que farão nascer o dia e cessar todos os encantos: 
Ao som de tambores de uma caixa de madeira com quatro cordas, o grupo brasileiro Usina do Trabalho do Ator apresentou a obra Mundéu, o Segredo da Noite, diante de mais de 700 pessoas. O espetáculo foi encenado ao ar livre, às 20h20, no Parque Urbano. Em meio ao vento frio que açoitou a noite, o grupo demonstrou sua capacidade para comunicar sentimentos e emoções prescindindo quase totalmente da linguagem oral. Nos quase 60 minutos que durou a obra, os cânticos e o manejo da expressão corporal e gestual se combinaram para narrar a história [...] A maquiagem, o figurino e a música acompanharam e complementaram o espetáculo que encantou o público por seu colorido e dinamismo (Rituales..., 1999, p. C4. Tradução nossa).

Para o grupo, nesse espetáculo a antropofagia é empregada de maneira mais profunda. A devoração cultural torna-se efetivamente procedimento no qual as influências técnicas são incorporadas e assimiladas ao contexto do universo investigado: a pesquisa sobre o carnaval, presente desde Klaxon, é associada ao estudo da dança do Sul da Índia, o Bharatanatyam, manifestação em que pantomima, dança e música se misturam. Toda a ação do espetáculo é uma narrativa encenada, a partir de sua rica codificação de gestos, passos e ritmos. Pode-se dizer que existe certa semelhança com o modo como Eugenio Barba se aproxima da Índia, segundo a análise de Patrice Pavis em sua teoria do interculturalismo na encenação teatral contemporânea, na qual distingue diferentes modos de transferência cultural comparando abordagens de Peter Brook, Ariane Mnouchkine e Eugenio Barba.

Na sua "adaptação" do Fausto de Goethe, Barba faz improvisarem uma dançarina indiana e uma dançarina japonesa. A imagem da Índia é, portanto, mais do que marginal: ela se exprime apenas por meio da modelização artística da dança odissi, a qual é fortemente retrabalhada pela improvisação de Sanjukta Panigrahi, ainda, a cultura medieval em que se banha o Fausto e a cultura goetheana são totalmente obliteradas e substituídas, ainda que muito parcialmente, por uma coreografia vagamente inspirada pelas danças odissi e buyo (Pavis, 2008, p. 183).

Assim como na encenação de Barba, onde a cultura de fora é apresentada e transmitida para o público ocidental, na 
montagem de Usina do Trabalho do Ator, a aculturação se dá pelo interesse no comportamento estrangeiro, sem a necessidade de tornar compreensível a cultura de referência. Com a segmentação das ações, os atores realizam um equivalente da ação real, compondo-as de uma maneira afastada da forma cotidiana de comportamento. Para Eugenio Barba, conforme Gilberto Icle, o ator se distancia da sua espontaneidade, ou seja,

[...] da forma cotidiana de falar, andar, olhar, construindo uma 'segunda natureza'. É esta forma de aculturar o 'corpo-ator' que garante não só uma expansão das energias (tensões musculares) que estão íntima e irremediavelmente ligadas às emoções, como também uma expansão da percepção cinestésica do espectador (Icle, 2002, p. 91).

Somado a isso, a ideia de um teatro canibal pressupõe que, depois de devorar o universo fonte, ocorra a transformação da natureza do material ingerido. Este procedimento faz parte do processo de criação do espetáculo, no objetivo de fundir as lendas do Sul: o que aconteceria se os personagens de uma lenda encontrassem os de outra lenda? Por exemplo, se Anhangá-Pitã, personagem da lenda A Salamanca do Jarau, encontrasse a Boitatá, uma cobra que dá nome a outra lenda do sul do Brasil? O resultado dessa deglutição é a fusão das lendas:

Valendo-se de matéria-prima extremamente rica, a partir das lendas e contos elaborados por Simões Lopes Neto, no início do século, Gilberto Icle, em cerca de uma hora, desenvolve um enredo que mescla as personagens e suas funções, sem ater-se, contudo, aos enredos originais em que elas se apresentavam. Assim, acabamos encontrando uma espécie de atualização mítica daqueles que são os grandes desafios humanos. Em especial, o ultrapassamento da morte e a inteligência das coisas, tudo isso traduzido na posse ou perda dos olhos. [...] A coreografia é dos teatros tradicionais orientais e se aproxima do ritual religioso (Hohlfeldt, 1998, s. p.).

Portanto, em Mundéu, a apropriação/devoração acontece não só pelos temas escolhidos, mas pelo modo de fundi-los, num procedimento intertextual que altera a origem e fonte dos textos, alterando sua estrutura e o transformando radicalmente, 
ou mesmo deixando apenas um vestígio de sua origem e fonte, como aborda Fernando de Toro a esse respeito:

[...] um intertexto é uma inserção que ostenta seu texto e não deixa dúvidas sobre sua origem e fonte, enquanto que o palimpsesto efetua uma transformação radical no intertexto, alterando sua estrutura e deixando somente uma pegada, um vestígio de sua origem e fonte. Por fim, a intertextualidade rizomática não deixa nada atrás, somente um referente falso que oblitera o texto matriz e, de fato, ostenta a ausência de toda a fonte ou uma presença vazia simulada (Toro, 2008, p. 307).

A dramaturgia não é mais somente afeita aos personagens de Lopes Neto, tampouco à ação das lendas folclóricas, mas um encontro desses elementos com o grupo de atores, que resulta numa ação viva, numa experiência estética que dá novo sentido à tradição. A execução não se resume mais em dançar Bharatanatyam ou dança espanhola, fazer mímica ou teatro ocidental; mas, numa linguagem particular, que emerge desse processo, no qual os atores revelam-se através de suas máscaras e onde o todo é mais do que a soma das partes. Além disso, a aproximação com o ritual afro-brasileiro é um antigo caminho do grupo, iniciado em Klaxon e reutilizado em Mundéu.

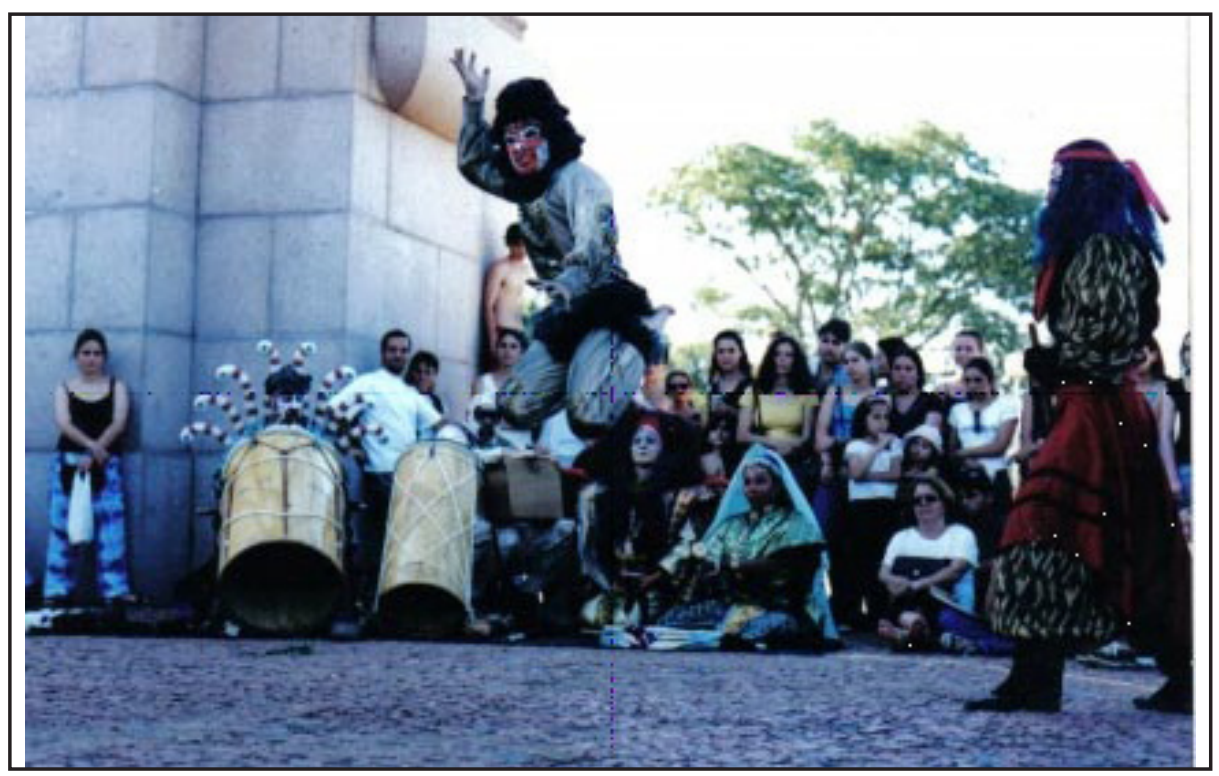

Figura 2 - Gilberto Icle e Márcio Müller (sentados: Leonor Melo, Chico Machado, Ciça Reckziegel e Celina Alcântara) em Mundéu, o segredo da noite, de 1998. Fotografia de Fábio Zambom. 
No terceiro espetáculo do projeto Trilogia Mascarada, $A$ Mulher Que Comeu o Mundo, de 2006, a pesquisa sobre diferentes possibilidades de atuação e encenação chega no que o núcleo chama de espaço múltiplo, preparando os atores para que o espetáculo possa ser realizado em qualquer lugar. $\mathrm{Na}$ verdade, numa grande diversidade de locais. Do palco à italiana à rua, passando por salas, galpões e outros espaços possíveis. Diferente das montagens anteriores, a meia-máscara, utilizada no espetáculo, confere expressão ao ator e lhe permite o uso da voz. O espetáculo é narrado por um coro de atores, figuras estranhas que cantam a história de uma mulher gorda que, ao perder o pai, começa a comer tudo, inclusive os vizinhos e a cidade. E, não satisfeita, come tudo o que aparece pela frente, ficando só. Ao mesclar ritmos e danças, tanto do Sul do país como de outras partes, o espetáculo conecta elementos de estruturas diversas e produz "[...] uma proliferação sem hierarquia, desunida, aberta e sempre em desenvolvimento" (Toro, 1994 apud Toro, 2008, p. 308) própria do rizoma. O mais instigante, no entanto, é o modo como enfatiza o caráter lúdico da encenação com suas canções, e por meio da figura da mulher que literalmente engole alguns espectadores/participantes, fazendo-os sumir por vários momentos por debaixo do imenso vestido da protagonista.

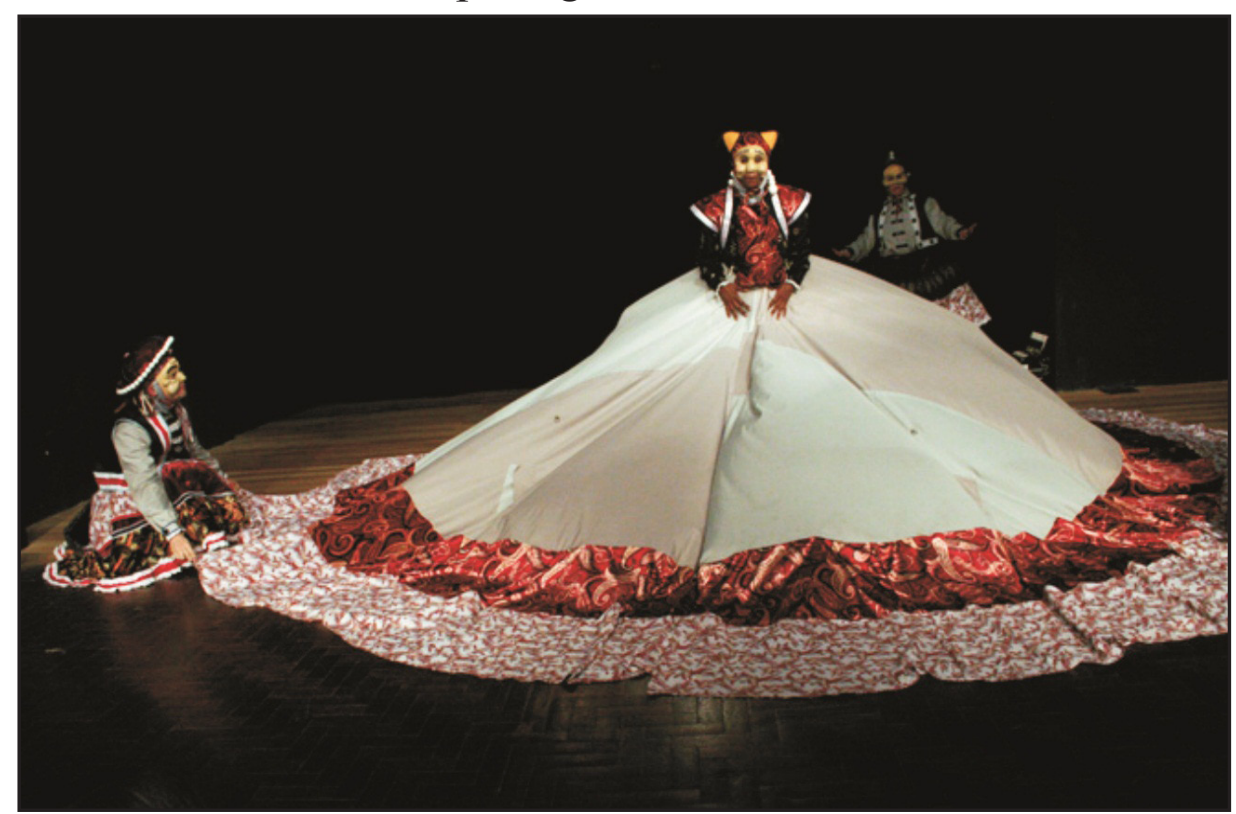

Figura 3 - Gilberto Icle, Celina Alcântara e Ciça Reckziegel em A mulher que comeu o mundo, de 2006. Fotografia de Myra Gonçalves. 
Ainda que o procedimento mais aparente seja a incorporação de elementos culturais de países como a Índia, através do acesso a modelos, fragmentos ou bens culturais que não são gerados em sua cultura local, é possível compreender a prática antropofágica do grupo como procedimento de transculturalidade, no sentido empregado por Alfonso de Toro (Villegas, 2010), pelo modo como o grupo constrói um campo de ação heterogênea não exatamente ao partir de uma cultura considerada externa, mas por refuncionalizar a ideia que se tem de uma cultura que se considera de base (no caso, a gauchesca, proveniente das lendas e contos do Sul), incorporando-a com a teatralidade oriental.

No entanto, ainda que nesses espetáculos o espectador seja requisitado corporalmente, a participação da plateia não reside no que se costuma considerar, no teatro ocidental, por uma participação ativa, tal como inúmeros artistas propuseram a partir de meados da década de 1960, com base na reformulação da relação palco-plateia, em oposição à configuração do palco italiano como determinante para uma recepção passiva do público, e que tem nos espetáculos do teatro ambientalista uma de suas frequentes realizações, com "[...] o rompimento dos acordos estabelecidos entre atores e espectadores" (Schechner, 1988, p. 75) nos espetáculos do The Performance Group. Compreender sua posição nos espetáculos citados da Usina do Trabalho do Ator é, antes de mais nada, entender que sua percepção sensorial é ativada pela teatralidade do tipo rásico, que prioriza os sentidos do espectador. Este tratamento é reconhecido pela forma como

[...] ao realizar Mundéu, o segredo da noite [...], Gilberto Icle alcança um excelente trabalho poético e perfeitamente eficiente enquanto linguagem. Não sei se podemos catalogar esse trabalho como infantil (ou melhor, dirigido para as crianças), mas é certo dizer-se que elas curtem o espetáculo e ficam absolutamente quietas, curiosas, acompanhando o desenrolar das cenas, ao longo de toda a apresentação (Hohlfeldt, 1998, s. p.). 

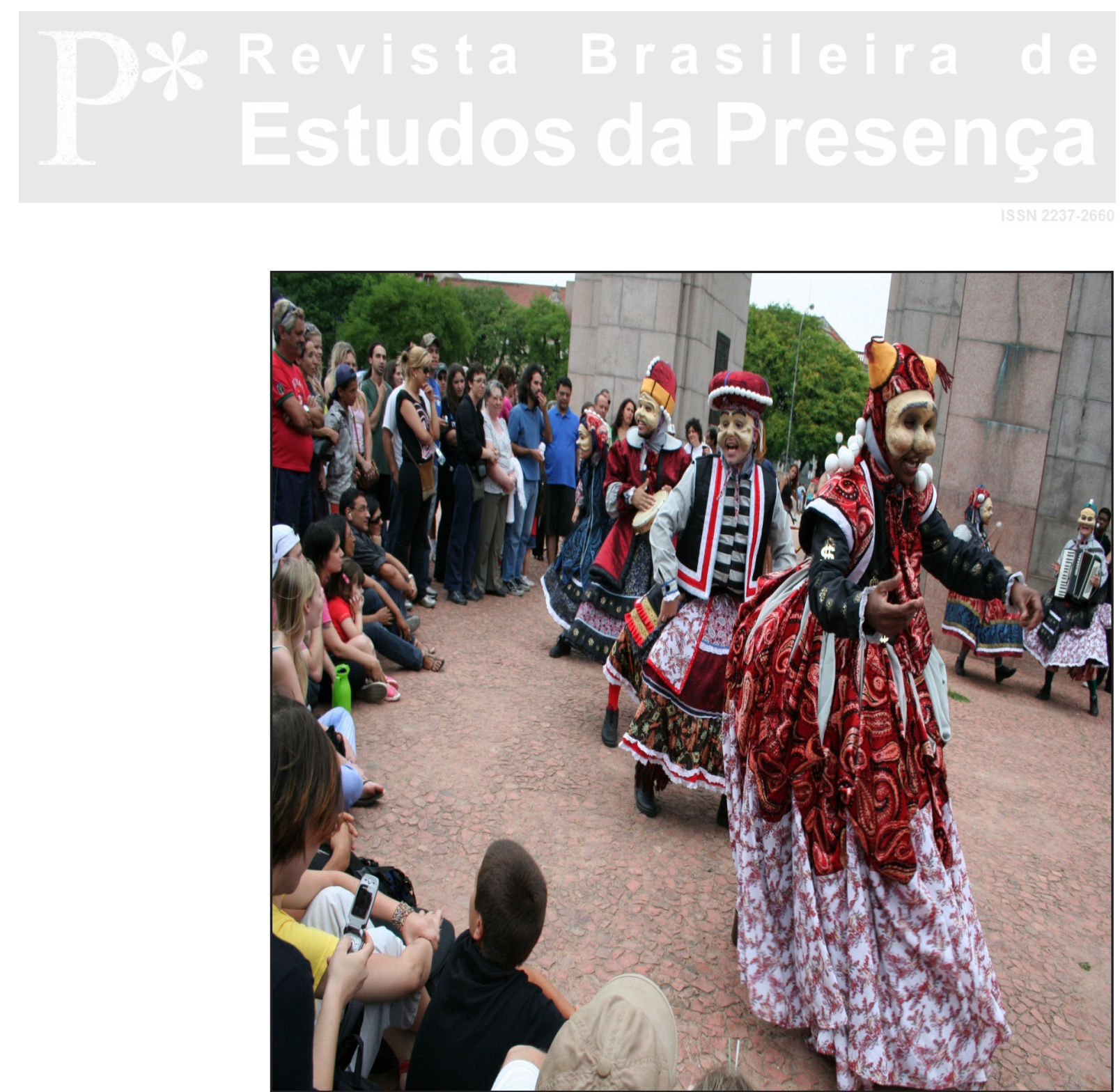

Figura 4 - Gisela Habeyche, Thiago Pirajira, Gilberto Icle e Celina Alcântara (ao fundo Dedy Ricardo e Ciça Reckziegel) em $A$ mulher que comeu o mundo, de 2006. Fotografia de Myra Gonçalves.

Enfim, pela alegria que se presentifica nos espetáculos da Usina, as propostas parecem congregar vários dos espectadores imaginários aos quais Eugenio Barba faz referência em seu texto $O$ espaço interno (2008), que dialogam com ele durante o processo de concepção da cena teatral, procurando envolver a criança que ainda não tem capacidade de abstração, o espectador surdo que capta o visual do espetáculo, o cego que percebe o espaço por meio do silêncio e da voz. E desafia Jorge Luis Borges, o quarto espectador, alguém que leu todos os livros e supostamente conhece tudo, a encontrar as fontes mais longínquas por meio das pegadas deixadas pelos atuadores. Ainda que, como na canção Um Índio, de Caetano Veloso, o que parecia estar bem distante se revele e surpreenda a todos não por ser exótico, mas pelo fato de poder ter sempre estado oculto. 


\section{Referências}

BARBA, Eugenio. O Espaço Interno. Sala Preta, Universidade de São Paulo, São Paulo, n. 8, p. 09-10, 2008.

FÉRAL, Josette. Teatro, Teoría y Práctica: más alla de las fronteras. Buenos Aires: Galerna, 2004.

GUÉNOUN, Dénis. O Teatro é Necessário? São Paulo: Perspectiva, 2004.

HOHLFELDT, Antônio. Espetáculo Inesquecível. Jornal do Comércio, Porto Alegre, s. p., 18 set. 1998.

ICLE, Gilberto. Teatro e Construção de Conhecimento. Porto Alegre: Mercado Aberto, 2002.

MARTINS, Rejane. O Ronco do Bugio vai Alegrar a Esquina Democrática. Zero Hora, Porto Alegre, 6 dez. 1996. Segundo Caderno. P. 06.

PAVIS, Patrice. O Teatro no Cruzamento de Culturas. Tradução de Nanci Fernandes. São Paulo, Editora Perspectiva, 2008.

RITUALES y Leyendas Brasileñas al Son de Música. El Deber, Santa Cruz de la Sierra, p. C4, 20 abr. 1999.

SCHECHNER, Richard. El Teatro Ambientalista. México: Árbol Editorial, 1988.

SCHECHNER, Richard. Performance, Teoría y prácticas Interculturais. Tradução de M. Ana Diz. Buenos Aires: Libro del Rojas, 2000.

TORO, Fernando de. La(s) Teatralidad(es) Post-moderna(s). Simulación, deconstrucción y escritura rizomática. In: TORO, Fernando de. Semiotica del Teatro. Buenos Aires: Galerna, 2008. P. 297-324.

VILLEGAS, Juan. Multicultutalismo e Multiteatralidades na América Latina. In: MOSTAÇO, Edélcio (Org.). Para uma História Cultural do Teatro. Florianópolis/Jaraguá do Sul: Design Editora, 2010. P. 87-108.

Clóvis Dias Massa é ator graduado em teatro pela Universidade Federal do Rio Grande do Sul, mestre em Artes Cênicas pela Universidade de São Paulo e doutor em Teoria da Literatura pela Pontifícia Universidade Católica do Rio Grande do Sul. Atualmente, é professor no Programa de Pós-graduação em Artes Cênicas da Universidade Federal do Rio Grande do Sul.

E-mail: clovismassa@terra.com.br

Recebido em 02 de julho de 2012 Aprovado em 27 de agosto de 2012 